\title{
PENGARUH LINGKUNGAN KOS-KOSAN TERHADAP MOTIVASI BELAJAR MAHASISWA STAKPN AMBON
}

\author{
Jondri Josias Toisuta \\ SEKOLAH TINGGI AGAMA KRISTEN PROTESTAN NEGERI AMBON \\ jondrisosias@gmail.com
}

\begin{abstract}
Motivation is the urge to achieve a particular goal. The research aims to determine if there is a KosKosan environmental influence on the learning motivation of students of the National Christian Religious School (STAKPN) Ambon. Research conducted on the STAKPN campus AmbonIn particular, the Department of Christian Religion (PAK) semester II (two), IV (four) and VI (six).

This research uses a quantitative type survey approach. The population of the study is all students majoring in Christian religious education Semester II (two), IV (four) and VI (six) who live in Kos-kosan amounting to 120 people. While the sampling of research samples was completed with two techniques namely the first is simple random sampling technique by looking at the table Isach and Michael and secondly using the purposional random sampling technique, then obtained research samples As many as 89 people. The data collection techniques used are questionnaire or questionnaire and non-participation observation.Research Data is analyzed with the help of SPSS type 16.0 Program. Data analysis includes description analysis, test prerequisite analysis and final analysis. Description The analysis of this study is the presentation of maximum value, minimum value, average value (Mean) and standard deviation. The prerequisite analysis test in this study is testing data normality and Linieritas data. The data normality test is done with the formula of Kolmogrov Smirnov and shows normal distribution data. The linierity test is performed and shows there is a linear relationship between the $X$ variables of the cost environment and the variable $Y$ learning motivation. Final analysis testing is conducted including regression test to provide for influence, coefficient of determination to know how much contribution or donations are given in the cost environment variable to learning motivation, and hypothesis testing To contribute significant and positive environmental influences to the motivation of learning. The results of the hypothesis testing proved there was a significant and positive influence marked by the T-count value of the > T table $(2,573>1,986)$ and the donations that were given $X$ variables of the cost environment against the Y Motivai variable studied at 0.71 or $7.1 \%$ as the rest $92.9 \%$ influenced by other variable-varibells
\end{abstract}

Keyword: cost environment, learning motivation

\section{Pengantar}

Saat ini banyak orang berlomba-lomba untuk menuntut ilmu demi mendapatkan banyak ilmu pengetahuan, mulai dari tingkatan yang paling rendah yakni pendidikan anak usia dini (PAUD), TK, SD, SMP, SMA maupun Perguruan tinggi. Pendidikan adalah suatu hal pokok yang amat penting dalam segi kehidupan manusia, sebab lewat pendidikan seseorang diajarkan dari ketidaktahuan menjadi tahu sehingga menjadi bermanfaat bagi dirinya sendiri. Bagi sebagian orang menjadi suatu kebanggaan karena bisa merasakan pendidikan dan mempersiapkan diri untuk masuk dalam dunia kerja. Fenomena dunia kerja saat ini, hampir sudah tidak lagi membutuhkan ijazah SMA disebabkan terbukanya lapangan pekerjaan yang semakin meluas dengan membutuhkan kualitas sumber daya manusia yang handal dan berkompetensi di berbagai bidang. Terkait hal tersebut, Maka lingkup pendidikan tidak hanya sebatas pada derajat SMA saja akan tetapi telah mencakup tahap-tahap lebih tinggi seperti pendidikan Sarjana (Strata 1), Magister (Strata 2), Doktor (Strata 3) dan bahkan merahi gelar terbaik Profesor (Guru besar).

Semua tingkatan pendidikan lanjutan ini dapat dijumpai pada perguruan tinggi (universitas). Perguruan tinggi adalah adalah satuan pendidikan yang menyelengarakan pendidikan tinggi. Barthos mengatakan bahwa Pendidikan tinggi adalah pendidikan pada jenjang yang lebih tinggi daripada pendidikan menengah dijalur pendidikan sekolah. Lebih lanjut Barthos menjelaskan bahwa tujuan pendidikan tinggi adalah a). Menyiapakan peserta didik menjadi anggota masyarakat yang memiliki kemampuan akademik dan atau profesional yang dapat menerapkan, mengembangkan dan menciptakan ilmu pengetahuan dan teknologi dan kesenian. b). Mengembangkan dan menyebar luaskan ilmu teknologi dan kesenian serta mengupayakan penggunaannya untuk meningkatkan taraf kehidupan masyarakat dan 
memperkaya kebudayaan nasional. (Basir Barthos:1992)

Perguruan tinggi sebagai satuan pendidikan yang menyelenggarakan pendidikan tinggi memberikan peranan penting dalam menciptakan sumber daya manusia yang berkualitas, karena saat ini kualitas sumber daya manusia dipandang sebagai salah satu faktor yang harus dipersiapkan untuk menghadapi persaingan pasar bebas. Semakin tinggi persaingan dan tuntutan dunia kerja membutuhkan sumber daya manusia yang berkualitas dan handal dalam segala kompetensi yang dimiliki sehingga mampu mengembangkan diri dan mampu membangun bangsa. Pada perguruan tinggi seorang individu bukan lagi sebagai siswa namun telah menjadi mahasiswa oleh sebab itu menjadi seorang mahasiswa harus bisa hidup mandiri di luar ketergantungan sepenuhnya kepada orang tua. Menjadi mahasiswa juga harus mampu menampilkan pribadi yang berkarakter, intelek dan bertingkah laku yang sopan santun, menghargai dan menghormati serta menjadi teladan bagi orang lain.

Mahasiswa merupakan garda terdepan bangsa karena mahasiswa memiliki daya kemampuan yang bisa merubah dan mentransformasikan nilainilai sosial kearah kehidupan yang lebih baik. Kemampuan seorang mahasiswa terletak pada kekuatan moral dan semangat perjuangan yang masih murni dan teruji. Oleh karena itu sebutan yang lasim digunakan untuk istilah mahasiswa adalah agen pembaharu dan penerus cita-cita bangsa dan negara. Adanya sejumlah perguruan tinggi di indonesia bertujuan untuk menghasilkan sejumlah kualitas mahasiswa sebagai sumber daya manusia yang memiliki kualitasbermutu dan diyakini dapat dipakai di masyarakat.

Mendengar munculnya lembaga perguruan tinggi negeri maupun swasta di indonesia menghendaki setiap pelajar yang telah menamatkan pendidikan menengah atas atau SMA banyak berdatangan ke daerah perkotaan di mana perguruan tinggi itu terletak untuk menuntut ilmu pada perguruan tinggi yang ditekuninya di berbagai besik keilmuan masing-masing yang dipilah sesuai pula dengan daya selera dan kemampuan. Di perguruan tinggi ditemui berbagai karakteristik perbedaan majemuk meliputi perbedaan dari berbagai aspek seperti perbedaan ekonomi,suku,etnis,kebudayaan,ras, kecerdasan intelek, maupun perbedaan asal-usul dari mana ia datang. Perbedaan-perbedaan keberagaman tersebut menandakan ciri khas masing-masing person dan Salah satunya paling banyak ditemukan pada perguruan tinggi STAKPN Ambon.

Mayoritas Mahasiswa STAKPN Ambon yang sementara menuntut ilmu saat ini bukan seutuhnya berasal dari masyarakat perkotaan yang berdomisili dan termasuk penduduk asli Ambon, namun mereka datang dari berbagai pedesaan yang jaraknya jauh maupun dekat dengan dengan kampus. Mahasiswa ini berasal dari berbagai pulau yang meliputi Lease, Seram, Buru, Tenggara, Tual, Tanimbar, Saumlaki, Kepulauan Aru, Tepa, dan bahkan Ternate maupun dari berbagai pesisir di sekitar kota Ambon. Oleh karena tuntutan pendidikan menghendaki setiap pelajar tamatan SMA harus meninggalkan rumah dan kampung halaman demi belajar dalam himpunan perguruan tinggi dan menjadi mahasiswa. Di samping itu juga dengan latar belakang kehidupan keluarga yang berbeda dari kalangan ekonomi menengah kebawah mereka datang untuk menempuh perkuliahan demi mencapai masa depan. Oleh karena tuntutan kebutuhan pendidikan lanjutan mengharuskan mereka harus berdomisili tinggal di Ambon selama kurang lebih empat atau lima tahun sampai batas akhir studi mereka. Bagi para mahasiswa terutama yang bukan penduduk asli perkotaan perguruan tinggi itu berada, sudah pasti akan menemui masalah vital yang berhubungan dengan dirinya yaitu dimana mereka harus tinggal selama rentang waktu belajar di perguruan tinggi tersebut.

Tempat tinggal adalah kebutuhan yang sangat penting dalam membantu mahasiswa selama proses perkuliahan. Dikatakan tempat tinggal sangat penting karena di tempat tinggal mereka dapat beristirahat setelah belajar di kampus atau selesai melakukan kegiatan-kegiatan lainnya. Tempat tinggal juga menjadi tempat untuk berlindung dari terik matahari ataupun hujan. Untuk itu para mahasiswa yang akan belajar di kampus sangat memerlukan tempat tinggal, apakah mahasiswa akan memilih tinggal dengan keluarga ataukah tinggal di tempat kos. Memilih kos-kosan yang sesuai dengan keinginan harus ada pertimbangan. Oleh sebab itu mahasiswa harus pandai-pandai dalam mencari tempat kos. salah satu pertimbagan yang mesti diperhatikandan dapat dijadikan sebagai panutan memilih rumah kos yang baik yaitu lingkungan tempat tinggal.

Kondisi lingkungan tempat tinggal menjadi sebuah pertimbangan mahasiswa sebab lingkungan 
sangat berpengaruh bagi kegiatan belajar mahasiswa. Mahasiswalah yang berhak memilih kondisi lingkungan yang kondusif untuk belajar atau penuh keramaian. Sebagai sebuah kebutuhan yang urgen, rumah kos dituntut untuk memberikan kondisi dan situasi lingkungan yang nyaman, aman dan sehat. Lingkungan yang mendukung itu seperti jaraknya dekat dengan kampus, tersediannya tempat makan, ada tempat foto copy,warnet atau tempat tempat lain yang menunjang kelangsungan hidup dan belajar. Pada Tempat tempat kos biasanya memiliki peraturan yang berbeda-beda dan ada banyak tempat kos yang tidak dijaga langsung oleh pemiliknya. Ada pula peraturanperaturan yang membatasi anak kos seperti penentuan jam berkunjung di waktu malam. Namun ada sebagian besar lagi yang kos pada kawasan yang sangat bebas. Kebebasan anak kos tanpa pengawasan orang tua agaknya dapat membentuk perilaku yang negatif, tidak adanya pengawasan orang tua membuat anak kos seenaknya melakukan apa saja sesuai keinginannya hingga terpuaskan, termasuk melakukan perbuatan-perbuatan asusila yang menyimpang yang tidak seharusnya mereka lakukan. Hal ini juga dilatari pergaulan bebas kota besar yang cenderung memengaruhi motivasi dalam belajar.

Mahasiswa yang hidup di kos-kosan sering disapa sebagai anak kos, ini selalu rentang terhadap pergaulan bebas karena kurang adanya pengawasan penuh dari orang tua sehingga terlontar dipikiran bahwa mereka memiliki kebebasan paten dalam mengorganisir hidupnya sendiri tanpa ada beban perintah dan larangan dari siapapun. Situasi demikian lebih-lebih lagi dapat menjerumuskan diri mereka bergaul pada lingkungan yang negatif sehingga dapat memengaruhi pola pikir, penyalahgunaan sikap dan motivasi dalam belajar semakin menurun sehingga berdampak pada prestasi belajar di kampus. Lingkungan tempat kos ini merupakan faktor utama yang dianggap memengaruhi cara belajar mahasiswa yang adalah anak-anak kos. Cara hidup di lingkungan akan menunjukan perilaku anak-anak kos tersebut.

Selain lingkungan tempat tinggal atau koskosan, Harga sewa kos menjadi sebuah hal penting dalam pertimbangan memilih rumah kos. Pemilihan rumah kos tentu akan diselaraskan dengan pendapatan orang tua mereka. sebab tidak semua orang tua penghuni kos dalam hal ini orang tua mahasiswa mampu membayar harga kos yang ditentukan pemilik kos.

Ketersediaan fasilitas yang memadai dalam kos pula berpengaruh pada harga sewa. Apabila fasilitas yang tersedia baik maka harga sewa kos pun akan semakin melonjak tinggi. Sebaliknya demikian apabila fasilitas yang disediakan pemilik kos kurang memadai maka harga sewa akan rendah. Fasilitas yang disiapkan oleh pihak pemilik kos dapat beragam seperti perlengkapan fasilitas kamar kos seperti meja dan kursi belajar, tempat tidur, lemari,alat penerangan, ruang yang layak, mempunyai perabotan masak dan penghuni kos hanya membawa pakaian saja tanpa harus memikirkan membawa barang-barang perlengkapan yang diperlukan.

Berdasarkan hasil pengamatan awal yang dilakukan oleh penulis maka penulis menemukan bahwa sebagian besar anak kos hanya memilih kos tanpa memperhatikan beberapa pertimbangan seperti yang dijelaskan di atas, salah satunya lingkungan kos-kosan tersebut dengan berbagai fasilitas. Lingkungan koskosan yang dipilih itu kurang menunjang untuk merangsang motivasi belajar mahasiswa STAKPN Ambon. Fokus penelitian ini tertuju kepada mahasiswa yakni mahasiswa jurusan Pendidikan Agama Kristen semester dua, empat dan enam.

Lingkungan yang ditempati mahasiswa berada pada jalur bebas kontrol orang tua maupun pemilik kos, sehingga tidak ada sosok motivator yang baik dan membuat anak-anak kos yang merupakan mahasiswa ini lebih menghabiskan waktu bermain daripada belajar. Hal lain yang ditemui pada saat penulis melakukan wawancara ialah kurangnya ketersediaan fasilitas jasa kos yang memadai untuk mendukung proses belajar mahasiswa di kos, seperti meja dan kursi untuk belajar, lemari tempat buku-buku, ruas kamar yang ditempati begitu sempit, ruang yang tidak memiliki ventilasi, tidak ada warnet atau internet yang sewaktu-waktu dapat digunakan untuk belajar, berkaitan dengan berbagai kendala yang membuat mahasiswa kurang bermotivasi untuk belajar ditempat tinggal atau kos mereka, sehingga membuat sebagian mahasiswa STAKPN Ambon lebih memilih mengerjakan pekerjaan yang diberikan dosen di kampus. Pekerjaan yang dilakukan di kampus bertepatan dengan jam-jam kuliah sehingga mengganggu proses perkuliahan yang diberikan dosen bersangkutan. Lebih fatal lagi ialah ada tugas-tugas kuliah yang diminta 
untuk dikumpulkan, mereka tidak dapat mengumpulkan sebab tugas yang diberikan belum dikerjakan dan bahkan ada yang baru dikerjakan pada waktu kuliah berlangsung.

Terhadap paparan yang dijelaskan di atas maka kondisi lingkungan tempat tinggal mahasiswa yang adalah anak-anak kos merupakan salah satu variabel yang diduga berpengaruh terhadap motivasi belajar mahasiswa. Sebab lingkungan menjadi sebuah faktor yang mempengaruhi kehidupan manusia seperti yang dijelaskan dalam teori empirisme yang dipelopori oleh Jhon Locke bahwa perkembangan setiap individu dipengaruhi oleh pengalamanpengalaman yang diperoleh. (Sumandi Suryabrata:2014) Berdasarkan uraian permasalahan di atas maka penulis merasa tertarik untuk melakukan penelitian dengan judul "Pengaruh Lingkungan Kos-Kosan Terhadap Motivasi Belajar Mahasiswa STAKPN Ambon."

\section{Tinjauan Literatur}

\subsection{Lingkungan Kos-kosan}

Manusia pada hakikatnya selalu hidup dalam sebuah lingkungan baik itu lingkungan yang bersifat negatif maupun lingkungan yang bersifat positif. Di lingkungan tempat kelangsungan hidup seluruh makhluk hidup saling melakukan hubungan interaksi mempengaruhi dan dipengaruhi.

Menurut Munib mendefenisikan ingkungan secara umum diartikan sebagai kesatuan dengan semua benda, daya keadaan dan makhluk hidup termasuk manusia dan perilakunya, yang mempengaruhi kelangsungan peri kehidupan dan kesejaterahan manusia serta makhluk hidup lainnya. (Munib Achmat:2009) Oemar Hamalik mengemukakan pendapatnya tentang pengertian Lingkungan adalah segala sesuatu yang ada di alam sekitar yang memiliki makna dan pengaruh tertentu kepada individu. Lingkungan adalah segala sesuatu yang disekeliling manusia yang dapat mempengaruhi tingkah laku secara langsung maupun tidak langsung. (Oemar Hamalik:2003)

Sertain dalam Dalyono mengatakan bahwa lingkungan (environment) adalah semua kondisikondisi dalam dunia yang dalam cara-cara tertentu mempengaruhi tingkah laku kita, pertumbuhan, perkembangan atau life processes kita kecuali gengen, dan bahkan gen-gen dapat pula dipandang sebagai menyiapkan lingkungan bagi gen-gen yang lain. Sementara Dalyono sendiri mengatakan bahwa lingkungan itu sebenarnya mencakup segala material dan stimulus di dalam diri dan diluar diri manusia atau individu, baik yang bersifat fisiologis, psikologis maupun sosial kultur. (Dalyono:2010) Untuk memahami lingkungan yang diartikan dalam ke tiga istilah tersebut, maka dapat dijelaskan sebagai berikut:

a. Secara Psiologis, lingkungan meliputi segala kondisi dan material jasmani didalam tubuh, misalnya gizi, vitamin, air, peredaraan darah dan sebagainya.

b. Secara Psikologis, lingkungan mencakup segenap stimulus yang diterima oleh individu mulai sejak dalam kandungan, kelahiran dan matiya. Misalnya seperti sifat-sifat genes, interaksi genes, selera, perasaan dan sebagainya.

c. Secara Sosio Kultural, lingkungan mencakup segenap stimulus, interaksi, dan kondisi dalam hubungannya dengan perlakuan ataupun karya orang lain. Misalnya pola hidup keluarga, pola hidup masyarakat, pergaulan kelompok, latihan, belajar, pendidikan, pengajaran dan sebagainya. (Oemar Hamalik:2003)

Suryabrata, mengemukakan bahwa lingkungan adalah segala sesuatu yang berbeda diluar individu, dimana dalam keseluruhan tingkah lakunya individu tersebut berinteraksi dengan lingkungannya, baik di sadari maupun tidak disadari, langsung maupun tidak langsung. (Sumandi Suryabrata:2006)

Lingkungan belajar penting dan berpengaruh terhadap motivasi belajar mahasiswa sebagai subjek yang belajar. Selain sekolah dan keluarga, lingkungan tempat tinggal atau kos juga dapat digunakan sebagai salah satu lingkungan belajar yang dapat meningkatkan motivasi belajar mahasiswa. Lingkungan kos-kosan dapat dijadikan sebagai tempat mahasiswa belajar mengerjakan seluruh tugas-tugas perkuliahan yang diberikan. Lingkungan kos-kosan yang kondusif akan menciptakan suasana belajar mahasiswa yang enak dan nyaman serta terhindar dari keributan. Bila terjadi demikian maka akan membangkitkan motivasi belajar yang tinggi serta antusiasisme mendorong mahasiswa giat belajar untuk memperoleh indeks prestasi yang diharapkan.

Oemar Hamalik kemudian membagi lingkungan belajar menjadi empat macam yang meliputi: 
1. Lingkungan sosial adalah lingkungan masyarakat baik kelompok besar atau kelmpok kecil

2. Lingkungan personal yang meliputi individuindividu sebagai suatu pribadi berpengaruh terhadap individu lainnya.

3. Lingkungan alam (fisik) yang meliputi semua sumber daya alam yang dapat diberdayakan sebagai sumber belajar, dan

4. Lingkungan kultur mencakup hasil budaya dan teknologi yang dapat dijadikan sumber belajar dan dapat menjadi faktor pendukung pengajaran.

Sertain dalam Dalyono M membagi lingkungan menjadi tiga macam yaitu:

a. Lingkungan alam/ luar ialah segala sesuatu yang ada dalam dunia ini yang bukan manusia. misalnya rumah, tumbuh-tumbuhan, air, iklim hewan dan sebagainya

b. Lingkungan dalam ialah segala sesuatu yang termasuk lingkungan luar/alam.

c. Lingkungan sosial ialah semua orang/manusia lain yang mempengaruhi kita. misalnya, teman, keluarga, kawan sekolah dan sebagainya. (Dalyono: 2010)

Menurut E. P Hatubarat, ada beberapa faktor yang mempengaruhi lingkungan belajar yaitu sebagai berikut: (Hutubarat:1995)

\section{Penerangan}

Cahaya penerangan diruangan tempat kita belajar ditempat kita tinggal haruslah cukup. Penerangan yang paling terbaik sebenarnya adalah sinar matahari.Umumnya yang digunakan sebagai alat penerangan adalah lampu. Ruang yang cukup terang membuat suasana hati gembira. Sedangkan ruangan yang kurang terang menimbulkan kesuraman dan perasaan hati tercekam. Juga penerangan yang tidak cukup dapat membuat kepala pening, lekas letih,mata

perih, sering membuat kesalahan dan tidak tahan lama berkonsetrasi kepada pelajaran.

Dalam mengatur penerangan di tempat belajar, ada beberapa hal yang perlu

diperhatikan:

a. Harus cukup terang. Semakin kecil huruf atau angka yang kita baca atau lihat, semakin besar penerangan yang diperlukan. Sekurangkurangnya kita menggunakan lampu yang berkekuatan 60 watt.

b. Hindari kesilauan. Kesialuan timbul dari cahaya yang sangat terang di daerah pandangan kita. Perlu dijaga agar meja kerja kita,tidak turut menyilaukan,walaupun sedikitpun.

c. Sumber penerangan haruslah diatas pandangan kita. Dengan demikian kita akan terhindar dari cahaya yang langsung masuk kemata kita dari sumbernya.

\section{Ventilasi}

Yang dimaksud dengan ventilasi adalah keadaan peredaraan udara di dalam ruangan tempat kita belajar.secara umun dapat dikatakan ventilasi itu harus memungkinkan beredarnya udara bersih untuk dihirup dan suhu udara yang membuat suhu badan dalam keadaan adem. Udara segar memang sangat penting, karena udara yang tidak segar dapat menimbulkan penyakit pernafasan. Udara yang keluar dari tubuh manusia mengandung berbagai ragam sumber penyakit. Ruang yang ventilasinya baik, diman tidak ada angin berembus penting sekali, agar benih penyakit tidak sempat berkumpul dan menghindari kekurangan oksigen dan kelebihan karbondioksida.

\section{Suhu udara}

Suhu badan bukan saja dipengaruhi suhu udara, tetapi juga oleh kandungan uap udara dan kecepatan gerak udara, dan oleh radiasi tubuh kita kepada benda-benda disekeliling kita. Kalau kita melaksanakan tugas dengan memakai otak atau pikiran, suhu udara yang terbaik adalah antara $60^{\circ}$ $70^{\circ}$ F. Suhu udara sebenarnya tidak terlalu berpengaruh terhadap kemampuan berfikir, asal jangka waktunya tidak terlalu lama.

\section{Tempat belajar}

Sebaiknya kita mempunyai tempat belajar yang tetap disuatu tempat. Tempat yang tetap ini memberikan suasana yang cocok dan mendorong untuk belajar. Buku dan alat belajar yang diperlukan tidak perlu lagi kita pindahkan ketempat lain. Kita juga dapat mengusahakan agar disekitarnya tidak terlalu bising. Akan tetapi tempat yang seperti itu tidak selamanya dapat kita peroleh karena mungkin jumlah ruangan dirumah orang tua kita atau di tempat pemondokan tidak mengisinkankan kita memiliki ruangan tidur dan ruangan belajar sendiri. mempunyai kamar sendiri untuk belajar, bukanlah satu jaminan bahwa kita dapat belajar dengan penuh perhatian. Apalagi ditempat belajar ini ada tape recorder atau video, maka alat-alat ini akan dapat menganggu kita 
belajar, jika kita tidak berdisiplin menggunakannya. Tekat belajar memang harus kuat dan konsekuen dilaksanakan. Tekad inilah yang kadang-kadang, apalagi kalau kita seorang diri saja di kamar dan tidak ada orang lain mengawasi.

\section{Perabot belajar}

Cara belajar yang terbaik ialah dengan memakai meja dan kursi, dan duduk dengan tegak. Oleh karena belajar biasanya berlangsung beberapa jam, maka ukuran meja dan kursi harusllah diperhatika.Ukuran yang tidak sesuai dapat membuat kita lekas letih dan kurang dapat lama berkonsentrasi. Meja jangan terlalu kecil agar dapat menampung kertas, buku-buku dan alat-alat yang diperlukan dalam belajar sehari-hari. Tinggi kursi haruslah sedemikian ukurannya, sehingga kita dapat duduk dengan alas kaki kita dapat diletakan rata di atas lantai, sedang lekukan lutut dapat membentuk sudat siku-siku.

\section{Kebisingan}

Dewasa ini kebisingan meningkat terus. Kebisingan yang paling buruk pengharunya kepada orang yang bekerja, bunyi keras yang tidak kontinue. Seringkali kita tidak dapat menghindari kebisingan yang ada disekitar kita. Sebenarnya sikap kita sendiri terhadap suara yang ribut itu turut menentukan apakah kebisingan itu akan mengganggu kita belajar atau tidak.

Muhibbin Syah membagi lingkungan belajar menjadi dua macam yaitu lingkungan belajar sosial dan lingkugan belajar non sosial. Untuk memahami lebih dalam tentang lingkungan belajar sosial dan lingkungan belajar non sosil akan dijelaskan sebagai berikut: (Muhibbin Syah:2005) 1. Lingkungan belajar sosial meliputi:

a. Lingkungan sosial pendidikan, seperti guru/dosen, administrasi dan teman-teman sekelas dapat mempengaruh proses belajar seseorang siswa. Hubungan harmonis diantara ketiganya dapat menjadi motivasi bagi siswa untuk belajar lebih baik lagi.

b. Kondisi lingkungan masyarakat tempat tinggal siswa/mahasiswa akan mempengaruhi belajar siswa/mahasiswa.

c. Lingkungan sosial keluarga sangat mempengaruhi kegiatan belajar. ketegangan orang tua, sifat-sifat orang tua, demografi keluarga (letak rumah), pengelolahan keluarga, semuanya dapat memberi dampak terhadap aktivitas belajar.

2. Lingkungan Non sosial, meliputi:

a. Lingkungan alamiah, seperti kondisi udara yang sejuk, tidak panas atau tidak dingin, sinar yang tidak terlalu silau/kuat, atau terlalu lemah/gelap, suasana yang sejuk dan tenang. Lingkungan alamiah ini merupakan faktorfaktor yang dapat mempengaruhi aktivitas belajar. Sebaliknya bila lingkungan belajar tidak mendukung maka akan memperlambat kegiatan belajar.

a. Faktor instrument

Instrumen berhubungan dengan perangkat belajar yang di golongkan dalam dua macam yaitu yang pertama hardware seperti gedung sekolah, fasilitas belajar, dan sebagainya. Dan yang ke dua yaitu sofware misalnya peraturan sekolah, silabus, buku panduan dan sebagainya.

b. Faktor materi pelajaran

Faktor ini di sesuaikan dengan kondisi perkembangan usia seseorang dalam belajar.

Darsono mengemukakan bahwa Lingkungan belajar merupakan unsur-unsur yang datang dari luar diri peserta didik. Unsur-unsur tersebut meliputi kondisi lingkungan yang sehat, kerukunan hidup, ketertiban pergaulan, lingkungan yang aman, tentram, tertib dan indah. (Darsono:200)

Berdasarkan teori-teori para ahli psikologi pendidikan tentang lingkungan belajar yang dipaparkan diatas maka dapat disimpulkan bahwa lingkungan koskosan termasuk dalam lingkungan belajar sosial tepatnya lingkungan belajar masyarakat yang sangat berpengaruh amat besar terhadap motivasi belajar mahasiswa. Lingkungan kos merupakan salah satu lingkungan belajar yang berasal dari luar diri individu. Dan yang menjadi indikator atau unsur-unsur penting dari lingkungan belajar yakni lingkungan tempat tinggal atau koskosan

tersebut ialah kodisi lingkungan kos itu sendiri yang meliputi kondisi lingkungan kos yang sehat, terbebas dari gangguan dan penyakit, terciptakan suasana hidup rukun antar warga kos dan masyarakat, dapat menunjukan ketertiban dalam bergaul di lingkungan serta diharapkan terjalin pergaulan-pergaulan positif sehingga kehidupan tampak indah aman dan nyaman.

\subsection{Motivasi belajar}

1. Pengertian Motivasi 
Motivasi berasal dari bahasa latin yaitu Movere, yang berarti dorongan atau daya pengerak. (Hasibuan:2010) Motivasi menjelaskan apa yang membuat orang melakukan sesuatu, membuat mereka tetap melakukanya, dan membantu mereka dalam menyelesaikan segala pekerjaannya. Kata motivasi seringkali juga diartikan dengan kata motif diartikan sebagai daya upaya yang mendorong seseorang untuk melakukan sesuatu. Dalam kegiatan belajar mengajar, motivasi dapat dikatakan sebagai keseluruhan daya penggerak didalam diri anak yang menimbulkan kegiatan tertentu. (Sardiman:1996) Sejalan dengan itu Isbandi Rukminto dalam Hamza B Uno mengemukakan pendapatnya tentang pengertian motivasi berasal dari kata motif yang dapat diartikan sebagai kekuatan yang terdapat dalam diri individu yang menyebabkan individu tersebut bertindak dan berbuat. (Uno:2014) Motif tidak dapat diamati secara langsung, tetapi dapat di interpretasikan melalui tingkah lakunya berupa: rangsangan, dorongan atau pembangkit tenaga munculnya suatu tingkah laku tertentu.

Mc. Donal dalam Sardiman juga berpendapat motivasi adalah perubahan energi dalam diri seseorang yang ditandai dengan munculnya feeling dan didahului dengan tanggapan terhadap tujuan. (Sardiman:1996) Pengertian ini mengandung tiga elemen penting:

1. Motivasi terjadi mengawali perubahan energi pada diri setiap individu manusia, karena menyangkut perubahan energi manusia, maka penampakannya menyangkut keadaan fisik

2. Motivasi muncul dengan ditandai rasa/Feeling, afeksi seseorang. Artinya motivasi relevan dengan persoalan kejiwaan afeksi dan emosi yang dapat menentukan tingkah laku seseorang

3. Motivasi akan dirancang karena adanya tujuan, artinya merupakan respon dari suatu aksi yaitu tujuan.

Soetomo mendefenisikan motivasi sebagai suatu perubahan tenaga yang ditandai oleh dorongan efektif dan reaksi-reaksi pencapaian tujuan. Karena kelakukan manusia itu selalu bertujuan. (Soetomo: 2005) Mulyasa kemudian mengemukan bahwa Motivasi adalah tenaga pendorong atau penarik yang menyebabkan adanya tingkah laku ke arah suatu tujuan tertentu. (Mulyasa:2004)

Dalam kegiatan belajar, maka motivasi dapat dikatakan sebagai keseluruhan daya penggerak didalam diri siswa menimbulkan kegiatan belajar, yang menjamin kelangsungan dari kegiatan belajar dan memberikan arah pada kegiatan belajar, sehingga tujuan yang dikehendaki oleh subjek yang belajar itu dapat tercapai. (Sardiman:1996) Motivasi belajar lebih mengutamakan respon kognitif, yaitu kecenderungan siswa untuk mencapai aktivitas akademis yang bermakna dan bermanfaat serta mencoba untuk mendapatkan keuntungan dari

aktivitas tersebut.

Berdasarkan teori-teori yang diuraikan diatas dapat disimpulkan bahwa Motivasi belajar mengandung unsur dorongan dan keinginan yang berasal dari diri dan menjadi hal mutlak. Motivasi belajar merupakan dorongan dari dalam diri seseorang dalam usaha untuk memenuhi keinginan, maksud dan tujuan dalam proses belajar mengajar. Motivasi belajar sangat memegang peran penting dalam memberikan semangat dalam memacu energi seseorang untuk belajar.

\section{Fungsi Motivasi Belajar}

Tanpa adanya motivasi (dorongan) maka usaha seseorang tidak akan tercapai hasilnya begitu juga sebaliknya. Demikian juga dalam mencapai hasil belajar. Belajar akan lebih baik jika selalu disertai dengan motivasi yang sungguh-sunggguh, motivasi mempunyai peran dan fungsi yang sangat penting antara lain:

Menurut Sardiman ada tiga fungsi Motivasi belajar:

a. Mendorong manusia untuk dan berbuat. Jadi penggerak atau motor yang melepaskan energi

b. Menentukan arah perbuatan, yakni kearah perbuatan suatu yang hendak dicapai

c. Menyeleksi perbuatan, menentukan perbuatan mana yang harus dilakukan sesuai guna mencapai tujuan. (Sardiman:2011)

Menurut Oemar Hamalik ada tiga fungsi motivasi: (Oemar Hamalik:2003)

a. Mondorong timbulnya suatu kelakuan atau perbuatan. Tanpa adanya motivasi maka tidak akan timbul perbuatan seperti belajar

b. Motivasi berfungsi sebagai Pengarah. Artinya mengarahkan perbuatan ke arah pencapaian tujuan

c. Motivasi berfungsi sebagai penggerak. Besar kecilnya motivasi menentukan cepat lambatnya suatu pekerjaan

Berdasarkan pernyataan diatas maka dapat diketahui bahwa selain fungsi motivasi dalam 
belajar yaitu dapat mendorong serta memacu belajar siswa namun disamping itu motivasi belajar membantu untuk memilih tingkah laku yang pantas dalam mendukung tujuan belajar.

\section{Ciri-ciri Motivasi belajar}

Menurut Sardiman, ciri-ciri Motivasi belajar yaitu sebagai berikut: (Sardiman:2011)

a. Tekun menghadapi tugas

b. Ulet menghadapi kesulitan

c. Menunjukan minat terhadap macam-macam masalah

d. Lebih senang bekerja mandiri

e. Tidak cepat bosan terhadap tugas-tugas rutin

f. Dapat mempertahankan pendapatnya

Ciri-ciri di atas tersebut bila di miliki oleh seorang mahasiswa tentu ia akan memiliki motivasi yang cukup kuat. Ciri-ciri ini sudah tentu sangat penting dalam sebuah kegiatan belajar mengajar. Dalam kegiatan belajar mengajar akan tampak lebih baik, bila mahasiswa tekun dan ulet dalam menghadapi segala pekerjaan atau tugastugas yang diberikan dosen secara mandiri tanpa meng copy paste milik orang lain. Mahasiswa yang memiliki motivasi juga tidak akan merasa bosan dan mengeluh ketika tugas-tugas yang begitu banyak menumpuk, ia selalu memiliki ide-ide baru dan mampu mempertahankan pendapatnya.

\section{Macam-macam Motivasi Belajar}

Ada berbagai jenis atau macam-macam motivasi belajar yang dapat ditinjau dari berbagai sudut pandang sebagai berikut :

a. Motivasi di tinjau dari dasar pembentukannya meliputi:

1. Motif-motif bawaan adalah motivasi yang dibawa sejak lahir, motivasi ini ada tanpa dipelajari. contoh: dorongan untuk makan

2. Motif-motif yang dipelajari adalah motif yang timbul karena dipelajari, contoh: dorongan untuk belajar

b. Motivasi menurut pembagian dari Woodworth dan Marquis dibagi menjadi:

1. Motif atau kebutuhan organis. Meliputi: kebutuhan untuk minum, makan,bernafas dan sebagainya.

2. Motif darurat, misalnya: dorongan untuk menyelamatkan diri, dorongan untuk membalas dan sebagainya.

3. Motif objektif, yaitu menyangkut kebutuhan untuk melakukan ekplorasi, manipulasi untuk merahi minat c. Motivasi jasmani dan rohani. Motivasi jasmani seperti refleks, insting dan sebagainya sedangkan rohani meliputi kemauan.

d. Motivasi Intrinsik dan Ekstrinsik

Motivasi intrinsik adalah motif-motif yang menjadi aktif atau berfungsi tidak perlu didorong dari luar, karena didalam diri setiap individu sudah ada dorongan untuk melakukan sesuatu. Motivasi intrinstik disini mencakup diri sendiri yang tergerak untuk melakukan kegiatan belajar tanpa ada unsur paksaan dari orang tua, maupun temanteman.

Motivasi ekstrinsik adalah motif-motif yang aktif dan berfungsi karena adanya dorongan atau rangsangan dari Luar. Motivasi ini mencakup dorongan dari pihak luar seperti teman, atau pacar yang mempengaruhi pelaku belajar untuk melakukan kegiatan belajar. Intinya ialah belajar yang dilakukan itu dikarenakan ingin mendapatkan nilai yang baik serta mendapatkan pujian.

Berdasarkan beberapa pembagian jenis atau macam-macam motivasi di atas maka dapat disimpulkan bahwa secara garis besar motivasi digolongkan menjadi dua jenis yaitu motivasi intrinsik (berasal dari dalam diri) dan motivasi ektrinsik (berasal dari luar diri). Motivasi intrinsik dapat dikatakan merupakan hal lahiriah. Contohnya seseorang yang selalu belajar tanpa disuruh dari pihak lain seperti pendidik, orang tua dan sebagainya, sedangkan motivasi ekstrinsik dikarenakan ada dorongan dari unsur luar seperti orang tua, pendidik/ guru atau dosen, teman dan sebagainya. Dari dua jenis tersebut Jenis motivasi intrinsiklah yang dianggap penting menjadi hal yang harus ditanamkan dalam diri setiap pelajar tingkat tinggi sehingga dapat tergerak selalu untuk belajar.

5. Faktor-faktor yang mempengaruhi motivasi belajar

Menurut Hamza B Uno mengatakan bahwa pada umumnya terdapat beberapa indikator atau unsur yang mendukung motivasi belajar: (1). Adanya hasrat dan keingian berhasil, (2). Adanya dorongan dan kebutuhan dalam belajar, (3). Adanya harapan dan cita-cita masa depan, (4). Adanya penghargaan dalam belajar, (5). Adanya kegiatan yang menarik dalam belajar, (6). Adanya lingkungan belajar yang kondusif. (Hamza: 2014)

Rifa'i Achmat menjelaskan bahwa ada enam faktor yang didukung oleh sejumlah teori psikologi dan penelitian terkait yang memiliki dampak 
substansial terhadap motivasi belajar peserta didik.

Ke-enam faktor yang dimaksud yaitu: (Achmad:2010)

\section{Sikap}

Sikap memiliki pengaruh kuat terhadap perilaku dan belajar peserta didik karena sikap membantu peserta didik dalam merasakan dunianya dan memberikan pedoman kepada perilaku. Sikap juga akan membantu seseorang merasa aman disuatu lingkungan yang pada mulanya tampak asing. Sikap merupakan produk dari kegiatan belajar. Sikap diperoleh melalui proses seperti pengalaman, pembelajaran, identifikasi, perilaku peran ( pendidik-murid, orang tua anak-anak, dan sebagainya). Karena sikap itu dipelajari, sikap juga dapat dimodifikasi dan diubah. Pengalaman baru secara konstan mempengaruhi sikap, membuat sikap berubah, intensif, lemah ataupun sebaliknya.

\section{Kebutuhan}

Kebutuhan merupakan kondisi yang dialami oleh individu sebagai suatu kegiatan internal yang membantu peserta didik untuk mencapai tujuan. Perolehan tujuan merupakan kemampuan melepaskan atau mengakhiri perasaan kebutuhan dan tekanan. Kebutuhan itu berada dalam jaringan atau memori manusia, dan kebutuhan itu dapat bersifat fisiologis, seperti, lapar, atau kebutuhan itu merupakan hasil belajar, seperti kebutuhan untuk berprestasi.

\section{Rangsangan}

Rangsangan adalah perubahan didalam presepsi atau pengalaman dengan lingkungan yang membuat seseorang bersikap aktif. Rangsangan secara langsung membantu memenuhi kebutuhan belajar peserta didik. Setiap peserta didik memiliki keinginan untuk mempelajari sesuatu dan memiliki sikap positif terhadap materi pembelajaran. Namun apabila mereka tidak menemukan proses pembelajaran yang merangsang, perhatianya akan menurun. Pembelajaran yang tidak merangsang mengakibatkan peserta didik yang pada mulanya termotivasi untuk belajar pada akhirnya menjadi bosan terlibat dalam pembelajaran.

\section{Afeksi}

Afeksi berkaitan dengan pengalaman emosional, kecemasan, kepedulian, dan pemilikan dari individu atau kelompok pada waktu belajar. Setiap lingkungan belajar secara konstan dipengaruhi oleh reaksi emosional peserta didik. Demikian pula karena peserta didik dalam belajar sering kali berkaitan dengan perasaan sukses dan gagal, maka perasaan personalnya secara terus menerus akan tidak menentu. Kegiatan emosi peserta didik pada kegiatan belajar itu memiliki pengaruh penting.

\section{Kompetensi}

Manusia pada dasarnya memiliki keinginan untuk memperoleh kompetensi dari lingkungannya. Teori kompetensi mengasumsikan bahwa peserta didik secara alamiah berusaha keras untuk berinteraksi dengan lingkunganya secara efektif. Peserta didik secara intrinsik termotivasi untuk menguasai lingkungan dan mengerjakan tugas-tugas secara berhasil agar menjadi puas. Demikian pula setiap orang secara genetik diprogram untuk menggali, menerima, berpikir, manipulasi, dan mengubah lingkungan secara efektif.

\section{Penguatan}

Penguatan merupakan peristiwa yang mempertahankan atau meningkatkan kemungkinan respon. Para pakar psikologi telah menemukan bahwa perilaku seseorang dapat dibentuk kurang lebih sama melalui penguatan positif atau negatif. Penggunaan peristiwa penguatan yang efektif seperti, penghargaan hasil karya peserta didik, pujian, penghargaan sosial, dan perhatian.

\section{Metode}

\subsection{Pendekatan Penelitian}

Pendekatan penelitian digunakan untuk mengetahui jenis penelitian yang digunakan. Penelitian menggunakan penelitian survey dengan jenis penelitian kuantitatif.

Efendi mengatakan bahwa metode penelitian survei adalah penelitian yang mengambil sampel dari satu populasi dan menggunakan kuisioner sebagai alat pengumpulan data yang pokok. (Efendi Sopian dan Tukiran:2012)

\subsection{Lokasi Penelitian}

Penelitian ini akan berlangsung tepatnya di kampus STAKPN Ambon

\subsection{Populasi dan Sampel}

Populasi dalam penelitian ini adalah semua mahasiswa STAKPN Ambon jurusan Pendidikan Agama Kristen yang merupakan anak-anak kos 
yang berjumlah 120 orang dan sampel yang akan diambil dalam penelitian ini sebanyak 89 orang

\subsection{Teknik pengumpulan data}

Teknik pengumpulan data yang digunakan ialah angket atau kuisioner dan observasi nonpartisipasi.

\section{Hasil}

Hasil Pengujian Hipotesis membuktikan ada pengaruh signifikan dan positif ditandai dengan nilai $\mathrm{t}$ hitung $>\mathrm{t}$ tabel $(2,573>1,986)$ dan sumbangan yang diberikan variabel $X$ Lingkungan Kos terhadap variabel Y Motivai belajar sebesar 0,71 atau $7,1 \%$ sedangakan sisanya $92,9 \%$ dipengaruhi oleh variabel-varibel lain

\section{Pembahasan}

Lingkungan Kos merupakan lingkungan tempat tinggal mahasiswa, di mana mahasiswa melakukan aktivitas yang tutut mempengaruhi perilaku individu tertentu. Sedangkan motivasi belajar adalah dorongan atau keinginan untuk melakukan sesuatu yang berhubungan dengan kegiatan belajar. Lingkungan kos adalah salah satu faktor eksternal yang berpengaruh terhadap tingkat motivasi belajar mahasiswa, dikatakan demikian sebab apabila kondisi lingkungan kos mampu menjawab kebutuhan yang menyangkut dengan kegiatan belajar di kos maka secara otomatis mahasiswa akan termotivasi untuk belajar, sebaliknya apabila kondisi lingkungan kos tidak mampu menjawab kebutuhan belajar yang diharapkan oleh mahasiswa maka mahasiswa tidak akan termotivasi untuk melakukan kegiatan belajar. Terhadap pernyatan ini ternyata lingkungan kos turut mempengaruhi motivasi belajar.

Penelitian yang dilakukan di STAKPN Ambon pada jurusan Pendididkan Agama Kristen ini bertujuan untuk mengetahui apakah ada pengaruh lingkungan kos -kosan terhadap motivasi belajar mahasiswa. Hasil akhir yang dijumpai peneliti setelah melakukan analisa data dan perhitungan beberapa pengujian menunjukan bahwa terdapat pengaruh positif dan signifikan lingkungan kos-kosan terhadap motivasi belajar mahasiswa. Hasil perhitungan dibuktikan dengan terpenuhinya syarat pengujian hipotesis yang diuraikan sebagai berikut :
Berdasarkan hasil pengujian Hipotesis (Uji t) yang dilakukan dengan perbandingan antara nilai $t$ hitung dengan $t$ tabel, dengan jelas menunjukan bahwa ternyata nilai t hitung $=2,573$ lebih besar dari nilai t tabel $=1,986$ atau $(2,573>1,986)$ artinya terdapat pengaruh signifikan dan positif lingkungan kos terhadap motivasi belajar. Dikatakan berpengaruh positif sebab hasil perhitungan menunjukan nilai positif dengan melihat pada 0,5 taraf kesalahan.

Terhadap hal diatas ternyata lingkungan sebagai sesuatu yang universal sangat berpengaruh dalam memotivasi seseorang untuk semangat dalam merahi puncak suksesnya belajar. Lingkungan yang diharapkan ialah lingkungan yang kondusif dan nyaman serta layak dalam menunjang proses belajar mahasiswa. Ini artinya bahwa faktor lingkungan disebut sebagai emperik atau pengalaman sebab di lingkunganlah individu mulai mengalami dan merasakan alam sekitarnya.

Sehubungan dengan pernyataan di atas demikian Danasaputra mengemukakan yang dimaksudkan dengan lingkungan adalah semua benda dan kondisi termasuk di dalamnya manusia dan aktivitasnya, yang terdapat dalam ruang di mana manusia berada turut mempengaruhi kelangsungan hidup serta kesejaterahan manusia dan jasad hidup lainnya. Sejalan dengan itu Darsono berpendapat bahwa Lingkungan adalah sesuatu yang ada di alam sekitar yang memiliki makna atau pengaruh tertentu kepada individu.

Didasarkan atas beberapa pendapat ahli yang dikemukakan di atas ternyata manusia secara mutlak tak bisa melepaskan diri dari pengaruh lingkungan, salah satunya yaitu lingkungan tempat tinggal bagi mahasiswa yang tinggal di kos atau yang lebih dikenal dengan lingkungan kos. Keberhasilan seorang mahasiswa dalam berlajar dan memperoleh prestasi bergantung pula seberapa besar motivasi mereka dalam belajar. Lingkungan kos yang tidak mendukung seperti kurangnya ketersediaan perabot belajar, kursi dan meja belajar, suhu udara yang tidak baik, tidak ada alat penerangan, suasana yang penuh kebisingan semua hal ini sudah barangtentu tidak menunjang kelancaran proses belajar mahasiswa dan sama sekali tidak merangsang mood atau keinginan mahasiwa untuk semangat belajar. Sebaliknya jika lingkungan kos yang ditempati mahasiswa adalah lingkungan yang layak, tercipta kondisi yang kondusif terbebas dari kebisingan, ketersediaan perabotan belajar, alat penerangan, suhu udara 
yang memungkinkan melakukan aktivitas belajar dijamin dapat dijadikan faktor-faaktor penunjang meningkatkan semangat mahasiswa untuk terus menerus belajar.

Hasil penelitian lapangan menunjukan bahwa lingkungan kos-kosan yang ditempati mahasiswa sama sekali tidak menunjang kegiatan belajar, hal ini disebabkan karena ditemukan ada kos-kosan yang digunakan mahasiswa untuk tinggal tetapi fasilitas-fasilitas kelengkapan belajar tidak memenuhi kebutuhan belajar mahasiswa, ditemukan ada kos-kosan yang tidak memiliki kelengkapan perabot belajar seperti tidak ada kursi dan meja belajar, dan buku-buku pelajaran, selain juga ada kos yang penerangannya terbatas seperti lampu yang terdapat di kamar kos hanya dinyalakan pada waktu malam, ruang kamar yang berukuran sempit dan tidak memiliki ventilasi, dan suasana kos yang ribut dengan suara penghuni yang kebanyakan dan bahkan suara-suara musik yang mengganggu kegiatan belajar mahasiswa.

Problematikan yang dijumpai di lapangan seperti masalah-masalah yang mengganggu kelangsungan aktivitas belajar mahasiswa itu demikian menyebabkan mahasiswa banyak yang kurang termotivasi untuk belajar di kamar kos. Sebagai tanda bahwa mereka tidak termotivasi untuk belajar di kamar kos terlihat dari sikap mahasiswa yang tidak tekun menyelesaikan tugastugasnya di kos disebabkan lingkungan kos dalam hal ini fasilitas kos tidak memadai sehingga banyak yang memilih menyelesaikan tugas di kampus daripada di kos. Akibat kurangnya fasilitas kos yang memadai juga menyebabkan mahasiswa malas untuk menyelesaikan tugas-tugas yang sulit. Selain itu juga sudah pasti perhatian dalam belajar akan sejenak terhenti jika salah satu unsur dari lingkungan kos tidak mendukung seperti penerangan yang kurang, atau udara yang kurang bersih atau juga tidak ada perabot belajar dan bahkan suara ribut akan menganggu fokus perhatian dalam belajar. Searah dengan hilangnya fokus perhatian menyebabkan pula keinginan untuk belajar pun hilang. Jika terjadi kehilangan konsentrasi dalam belajar akibat suara ribut atau gangguan dari pihak lain maka keingginan untuk belajar secara mandiri sudah tak lagi terpenuhi, akan lebih senang bila duduk bersama dan tanpa sadar proses belajar tidak lagi dilanjutkan. Lebih lanjut lagi jika suasana kos yang diharapkan memiliki kelengkapan fasilitas kos yang menunjang proses belajar tidak stabil maka secara otomatis individu mahasiswa akan merasa cepat bosan terhadap kegiatan belajar yang dilakukan. Misalnya jika salah satu indikator yaitu buku pelajaran tidak ada maka bagaimana bisa mahasiswa akan rutin menyelesaikan tugas-tugas dengan baik, yang terjadi adalah sudah barang tentu akan cepat merasa bosan terhadap tugastugas yang diberikan. Kebiasaan mahasiswa STAKPN yang sering nampak saat diberikan tugas ialah merasa cepat bosan terhadap tugas-tugas tersebut. Hal terakhir yang terjadi ialah bahwa akan mudah terpengaruh kepada orang lain menyebabkan tidak mampu mempertahankan pendapat yang dipunyai.

Semua indikator pembahasan di atas baik dari variabel $\mathrm{X}$ lingkungan kos maupun variabel $\mathrm{Y}$ motivasi belajar adalah hasil temuan dilapangan yang terbukti jelas melalui setiap jawaban yang diberikan responden penelitian pada saat dijalankannya kuisioner. Variabel terikat $\mathrm{X}$ yang menyatakan tingkat motivasi belajar mahasiswa memiliki nilai rata-rata (Mean) yaitu 95,42 bila diakumulasi dengan total butir pernyataan sebanyak 24 maka di peroleh nilai 3,97 mengindikasikan bahwa rata-rata tanggapan responden dalam menjawab pernyataan variabel $\mathrm{Y}$ motivasi berada pada kisaran alternative jawaban dengan bobot nilai 3 yaitu kadang-kadang, bahwa data yang diperoleh menunjukan kadang-kadang mahasiswa STAKPN termotivasi untuk belajar dan Kadangkadang pula mereka tidak termotivasi untuk belajar dan yang menjadi salah satu faktor yang membuat sebagian mahasiswa termotivasi ialah penyebab lingkungan kos yang tidak mendukung kesuksesan belajar mahasiswa.

Penelitian menunjukan ada pengaruh positif dan signifikan lingkungan kos terhadap motivasi belajar, di mana berdasarkan hasil perhitungan melalui bantuan SPSS for window versi 16,0 diperoleh besar pengaruh 7,1\% variabel lingkungan kos mempengaruhi motivasi belajar. Sedangkan sisanya $(100 \%-7,1 \%)=92,9 \%$ dipengaruhi oleh faktor-faktor lain yang tidak dimasukan dalam penelitian ini seperti faktor perhatian orang tua, lingkungan kampus, kebiasaan belajar, minat belajar dan sebagainya. Pengaruh sebesar $7,1 \%$ jika dianalisi ternyata dalam proses penelitan ketika angket dibagikan kepada 89 responden, didapati ada sebagian masyarakat yang tergolong dalam responden yang tidak serius dalam membaca dan menjawab pernyataan yang ada pada kuisioner, kemudian juga ada mahasiswa yang 
meminta teman atau kerabatnya yang bukan mahasiswa kos untuk membantu menjawab pernyataan yang ada dalam kusioner tersebut.

\section{Simpulan}

Berdasarkan permasalahan, tujuan penelitian, dan hasil analisa data penelitian, maka dapat disimpulkan sebagai berikut:

1. Terdapat pengaruh signifikan dan positif lingkungan kos-kosan terhadap motivasi belajar mahasiswa yang dibuktikan dengan pengujian hipotesis yang menunjukan bahwa nilai t hitung $>\mathrm{t}$ tabel, $(2,573>1,986)$ terhadap hal ini maka rumusan $\mathrm{Ha}$ (Hipotesis Alternatif) terpenuhi.

2. Kontribusi atau Sumbangan yang diberikan variabel X Lingkungan Kos kepada Variabel Y Motivasi Belajar sebesar 0,71 atau sebanding dengan $7,1 \%$ sedangkan sisanya 92,9\% dipengaruhi oleh variabel-variabel lain.

\section{Saran Dan Rekomendasi}

Berdasarkan kesimpulan diatas, maka peneliti hendak memberikan saran kepada:

1. Mahasiswa STAKPN Ambon. Mahasiswa hendaknya pandai dalam memilih tempat kos yang diharapkan dapat menunjang segala proses belajar dan memotivasi mahasiswa agar memperoleh prestasi yang memuaskan.

2. Pemilik Kos. Pemilik Kos (Bapak/Ibu Kos) hendaknya dapat memenuhi segala kebutuhan anak kos yang merupakan mahasiswa dimana kebutuhan urgen yang diharapkan adalah pemenuhan keperluan penunjang aktivitas belajar mahasiswa mulai dari saranaprasarana sampai pada terciptanya suasana yang kondusif untuk belajar.

3. STAKPN Ambon. Melalui penelitian ini diharapkan STAKPN Ambon sebagai Garda Pengembangan pengetahuan hendaknya melihat dan meninjau keberadaan lingkungan kos yang ditempati mahasiswa dan kemudian merekomendasikan kepada para mahasiswa kos-kosan agar menempati lingkungan kos yang kodusif, aman dan nyaman serta dapat meningkatkan motivasi untuk semakin giat belajar.

4. Peneliti Lanjut. Mengingat hasil penelitian ditemui bahwa sebagian besar motivasi belajar dipengaruhi oleh Variabel-variabel lain sebesar 92,9 \%, maka perlu dilakukan penelitian lanjut untuk mencari tahu pengaruh variabel-variabel tersebut seperti Perhatian Orang tua, Lingkungan Sekolah, Kebiasaan belajar, dan lain-lainnya.

\section{Ucapan Terima Kasih}

Dalam penulisan ini, ada banyak tantangan yang penulis hadapi, namun atas berkat, dan bantuan, bimbingan serta pengorbanan dari berbagai pihak, maka semuanya dapat dilalui. Untuk itu dengan rasa hormat dan ketulusan hati penulis mengucapkan terima kasih dan penghargaan yang sebesar-besarnya kepada :

1. Dr. Agusthina. Ch. Kakiay, M.Si, selaku ketua Sekolah Tinggi Agama Kristen Protestan Negeri Ambon yang telah memberikan kesempatan untuk penulis menyelesaikan skripsi pada lembaga pendidikan ini.

2. Dr. A. Siahaya, M.Th selaku Wakil Ketua I, Dr. W.Y Tiwery, M.Hum selaku Wakil Ketua II, dan Dr. A.Ch. Gazper, M.Sn selaku Wakil Ketua III yang telah memberikan kesempatan untuk penulis menyelesaikan Skripsi pada Lembaga Pendidikan Ini

3. R. Aralaha, M.Th dan K. Makulua, M.Pd.K Selaku Ketua dan Sekretaris Jurusan Pendidikan Agama Kriten yang telah membantu penulis dalam penyelesaian studi

4. Dr. S. L. Souissa, M.Th selaku Pembimbing I, dan F. Maatuku, M.Pd selaku Pembimbing II yang dengan penuh kasih, kesabaran dan ketulusan meluangkan waktu, tenaga dan pikiran, bahkan perhatian dan bimbingan bagi penulis dalam penelitian dan penulisan Skripsi

5. Dr.Ch. D.W Sahertian, M.Pd selaku Pengarah I sekaligus Penguji I dan R. L Wattimena, M.Pd selaku Pengarah II sekaligus Penguji II yang telah Mengarahkan penulis dalam seminar proposal hingga ujian Skripsi

6. W. Y. Hetharion, M.Pd selaku penasihat akademik yang senantiasa menjadi ayah dalam membimbing dan memberikan nasihat kepada penulis dalam proses perkuliahan sampai pada penulisan skripsi

7. R. Souhaly, M.Hum Selaku Dosen Pembimbing PKL-P yang selalu membantu penulis dalam memberikan arahan dan nasihat bagi penulis dalam proses perkuliahan.

8. Seluruh Dosen dan Pegawai Jurusan Pendidikan Agama Kristen yang telah membantu penulis dalam memberikan data penelitian untuk penulisan skripsi 
9. Untuk Ayahku tercinta: Bapak Rafel Josua Toisuta dan Ibuku tersayang Juliana Papilaya/Toisuta yang selalu ada bagiku, memberikan dukungan dan doa yang tulus sehingga penulis telah berada di puncak kesuksesan

10. Untuk kakak tersayang, Alvia Elvika Toisuta yang selama ini menjadi orang tua bagiku, selalu menemani dalam susah dan senang, memberi suport, dukungan doa dan penyemangat sehingga penulis dapat menyelesaikan studi

11. Bagi seluruh teman-teman seperjuanganku angkatan 2013 terkhususnya Enjel, Debbie, Amel, Maikel, Meysly, Lency, Lenor, Clara, Merry, Naomi, Megi, Martha, Likius ) terima kasih untuk kebersamaan, saling mengenal, saling membantu, menopang dan menjadi penyemangat bagi penulis untuk menyelesaikan studi tepat waktu.

12. Bagi seluruh pihak yang tak dapat disebutkan satu per satu yang turut membantu penulis selama masa study, meluangkan waktu, tenaga, pikiran dan biaya. Penulis sangat berterima kasih kepada semua mereka dan kiranya mohon maaf jika ada kesalahan yang dilakukan yang menyinggung perasaan.

Penulis menyadari sungguh bahwa penulisan Skripsi ini jauh dari kesempurnaaannya sebab penulis berkeyakinan sungguh bahwa "KESEMPURNAAN HANYA BERASAL DARI ALLAH". Skripsi ini masih memiliki banyak kekurangan dan keterbatasn untuk itu sangat diharapkan segala kritikan dan masukan positif yang membangun agar penulisan ini kedepannya lebih baik lagi.

Akhir kata penulis menyampaikan terimakasih, teriring salam dan doa, Tuhan Yesus Kristus sang pemberi berkat kiranya memberkati dan menyertai kita, sekalian.

\section{Pustaka Acuan}

Arikunto. S.,2013, Prosedur Penelitian, Suatu Pendekatan Praktek. Jakarta: Rineka Cipta. .2010, Prosedur Penelitian, Suatu Pendekatan Praktek. Jakarta: Rineka Cipta.

Basir Barthos., 1992. Perguruan Tinggi Swasta Di Indonesia, Jakarta: Bumi Aksara

Dalyono., 2010, Psikologi pendidikan , Jakarta: Rineka Cipta
E. P. Hutubarat., 1995, Cara Belajar, Jakarta: BPK Gunung Mulia

Efendi Sopian dan Tukiran., 2012.Metode Penelitian Survei. Jakarta: LP315.

Hadari. N., 2007, Metode Penelitian Bidang Sosial. Gajah Mada University Vers .

Hardi Budiyana. 2011, -Dasar Pendidikan Agama Krsiten. Karanganyar. Berita Hidup Seminari.

Hamza. B., Uno, 2014, Teori Motivasi dan Pengukurannya, Jakarta:BumiAksara

Muhibbin. Syah.,2005, Psikologi Belajar, Jakarta: PT Raja Grafindo Persada

Malayu, S P Hasibuan, 2010. Organisasi dan Motivasi, Dasar Peningkatan Produktivitas, Jakarta: Bumi Aksar

Max Darsono., 2000.Belajar dan Pembelajaran, Semarang: IKIP Semarang Perss

Mulyasa. 2004, Manajemen berbasis sekolah, Bandung: PT. Remaja Rosdakarya

Munib Achmat., 2009, Pengantar Ilmu Pendidikan. Semarang: UPT MKU UNNES

Oemar Hamalik.,2003, Proses Belajar Mengajar, Jakarta: PT Raja Grafindo Persada

Ridwan., 2013,Belajar Mudah Penelitian Untuk Guru - Karyawan Dan Peneliti Pemula. Bandung: Alfabeta

Rifa'i Achmad, 2010, Psikologi Pendidikan, Semarang: UPT, MKU UNES

Sardiman. A.M, 1996. Interaksi dan Motivasi Belajar.Jakarta: Raja Grafindo Persada

.,2011. Interaksi dan Motivasi Belajar Jakarta: Raja Grafindo Persada

Soetomo., 2005, Interaksi Dan Motivasi Belajar Mengajar. Jakarta: Raja Grafindo Graha. .2013, Metode Penelitian Kuantitatif, Kualitatif, dan $R \& D$.Bandung: Alfabeta

.2008, Metode penelitian Bisnis. Bandung: Alfabeta.

., 2013, Statistika Untuk Penelitian. Bandung: Alfabeta.

Sumandi. S., 2006, Psikologi Pendidikan. Jakarta: PT Raja Grafindo Persada

., 2014. Psikologi Pendidikan, Jakarta: PT Raja Grafindo Persada

Syofian Siregar, M.M, 2012, Statistika Deskriptif untuk penelitian, jakarta:PT Raja Grafindo Persada

Fredrik L Papilaya .2013.Pengharu Penggunaan Jejaring Sosial Facebook Terhadap Motvasi Belaja Anak di SMA Negeri 10 Ambon. Skripsi. Ambon:Sekolah Tinggi Agama Kristen Protestan 
Negeri (STAKPN) Ambon, jurusan pendidikan Agama kristen

Ira Oktaviana. Pengaruh Lingkungan Sekolah Terhadap Motivasi Belajar Siswa Kelas V Sekolah Dasar DI Daerah Binaan 1 kecamatan Limpung Kabupaten Batang. Skripsi. UNS Fakultas Ilmu Pendidikan. Semarang, Jurusan Pendidikan Guru Sekolah Dasar

Jaswir Efendi, Pengaruh Lingkungan Kos Terhadap Prestasi Belajar Mahasiswa Pendidikan Geografi (STKIP) PGRI Sumatera Barat. Skripsi. Jurusan Geografi. Sekolah Tinggi Keguruan dan Ilmu pendidikan (STKIP) Sumatera Barat. 